\title{
Magma mixing, mingling and hybridisation at different crustal levels: snapshots from 1.9 billion years of magmatism in south-eastern Greenland
}

\author{
Thomas F. Kokfelt, Samuel M. Weatherley, Jakob K. Keiding and Trygvi B. Árting
}

During field work in 2014, we investigated a suite of igneous intrusions in south-eastern Greenland between $65^{\circ}$ and $67^{\circ} \mathrm{N}$. Many of the intrusions show widespread evidence for juxtaposition of different magmas in the liquid state and subsequent mixing, mingling and hybridisation. Here we present field evidence for these processes from three areas that differ in age and geological setting. We discuss the significance of mingling, mixing and hybridisation features in the field area, motivated by their abundance in the area, the morphological variation between intrusions that were emplaced at different crustal levels, the implications for magma genesis in collisional and rift settings, and the implications for the interior dynamics of igneous bodies.

\section{Magmatism in south-eastern Greenland}

The magmatic history of south-eastern Greenland broadly falls into two episodes: (1) the Proterozoic Nagssugtoqidian orogeny and preceding subduction, and (2) the Palaeogene opening of the North Atlantic. The Nagssugtoqidian Orogen formed by a NE-SW collision between the Rae and the North Atlantic Cratons that started at c. $1880 \mathrm{Ma}$ and ended with a post-orogenic collapse at $c$. 1740-1690 Ma (see Kolb 2014 and references therein). Several intrusions and intrusive complexes are associated with the orogeny (Fig. 1). These include the $c$. $1885 \mathrm{Ma}$ Ammassalik Intrusive Complex, interpreted as originating in an island arc, several post-tectonic granites, and the intermediate to felsic Ikaasartivaq intrusive complex with an uncertain intrusion age of $1680_{-8}^{+10} \mathrm{Ma}$ (Kalsbeek et al. 1993). Three separate intrusions of diorite and tonalite are found north of Ikaasartivaq strait. The ages of these Palaeoproterozoic intrusions, their geotectonic setting and relationship to the other intrusive bodies are poorly constrained.

Intrusive complexes from the Palaeogene extend from $66^{\circ}$ to $75^{\circ} \mathrm{N}$. They were emplaced between $c .55$ and $25 \mathrm{Ma}$ (Larsen et al. 2014 and references therein) and encompass mafic to felsic compositions of alkaline to tholeiitic affinity in addition to carbonate-related lithologies (Nielsen 2002). The intrusive complexes and associated coeval lavas and coastparallel dyke swarms are all part of the Palaeogene North Atlantic Igneous Province (NAIP) that formed as a result of oceanic rifting under the influence of the ancestral Icelandic mantle plume (Brooks 2011).

In this contribution, we present evidence for magma mingling, mixing and hybridisation in south-eastern Greenland, focusing in particular on the Ammassalik Intrusive Complex, the Ikaasartivaq intrusive complex and the Kialineq Intrusive Centre.

\section{Magma mixing, mingling and hybridisation}

Magma mixing is a recognised process operating in most magmatic systems worldwide and may be a trigger for generating volcanic eruptions (Sparks \& Sigurdsson 1977). The term 'mixing' refers to a process where two magmas blend to form a new magma of intermediate composition. The extent to which the magmas blend or mix critically depends on differences in the rheological properties and the relative proportions of the juxtaposed magmas (Sparks \& Marshall 1986). Important parameters that determine the rheology of a given magma include temperature, composition and crystal load. For large property contrasts, the mixing process will

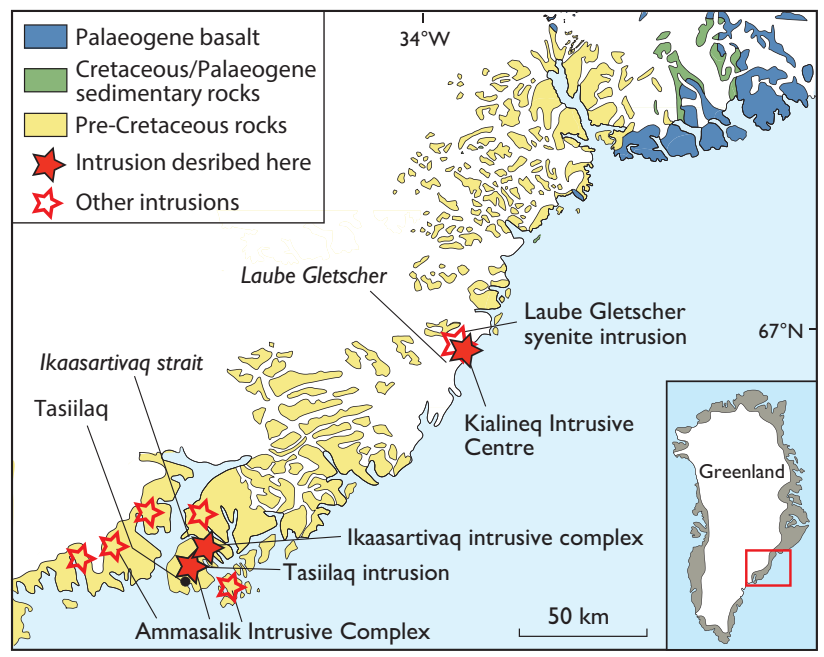

Fig. 1. Geological map of south-eastern Greenland showing some of the prominent intrusions and intrusive centres in the region. The intrusions described here are the $c .1885$ Ma Tasiilaq intrusion of the Ammassalik Intrusive Complex, the $c .1680$ Ma Ikaasartivaq intrusive complex and the c. 35 Ma Kialineq Intrusive Centre. 
typically be incomplete and the original magmas remain as identifiable units; the result is a mingled magma. Hybridisation refers to the general mixing process that may produce a range of variably heterogeneous intermediate magmas. Classical examples of magma mixing and mingling include eroded plutonic systems within the NAIP including Iceland (Brooks 2011). A common feature in many of these exhumed magma reservoirs is the occurrence of 'net-veined' complexes consisting of felsic, mafic and hybrid (intermediate) rocks.

Tasilaq intrusion of the Ammassalik Intrusive Complex The Tasiilaq intrusion, dated to $1886 \pm 2 \mathrm{Ma}$ (Hansen \& Kalsbeek 1989), is the central part of the Palaeoproterozoic Ammassalik Intrusive Complex that forms a c. $85 \times 20 \mathrm{~km}$ WNW-ESE-trending array of three large mafic intrusions (Fig. 1). The intrusion mainly comprises leuconorite that cross-cuts melagabbro, and late anorthosite and hypersthene veins that cross-cut the leuconorite and melagabbro. The wall rock is quartzofeldspathic garnet-rich gneiss, which has granulite facies assemblages close to the contact, and has been mobilised and mixed with the intrusive rock forming a marginal zone of hybrid rocks. Based on thermobarymetry and fluid inclusion data, Andersen et al. (1989) concluded that the intrusion crystallised at $c .1000-1100^{\circ} \mathrm{C}$ and $6-8$ $\operatorname{kbar}(c .18-24 \mathrm{~km}$ depth), i.e. in the middle to deep crust. In the field, melagabbro often forms 20-100 m wide trains within larger domains of leuconorite, defining the same gen- eral WNW-ESE-orientation as the overall structures of the Ammassalik Intrusive Complex. In some cases leuconorite has intruded melagabbro forming sharp angular contacts (Fig. 2A); in other outcrops, the two lithologies form lenticular intermingled bodies with smeared out, wavy contacts and with no chilled margins (Fig. 2B).

Ikaasartivaq intrusive complex - The Ikaasartivaq intrusive complex is composed of mafic and felsic intrusions, which straddles the Ikaasartivaq fjord $c .25 \mathrm{~km}$ north of Tasiilaq (Fig. 1). The complex measures c. $32 \times 25 \mathrm{~km}$ and comprises rocks of granitic, dioritic and gabbroic composition. It was first mapped by Wright et al. (1973), who described it as a late- or post-orogenic calc-alkaline suite related to the uplift of the area. These authors proposed that the complex was emplaced into relatively shallow crustal levels based on observations of sharp contacts between intrusive units and negligible evidence for contact or retrogressive metamorphism.

Mixing and hybridisation features within the intrusive complex are ubiquitous and show a range of styles and morphologies. In the main body of the complex, mingling features between diorite and granite are observed at millimetre- to metre-scales in the form of blobs and globules and occasionally as angular net-veined areas. Although mingling features are quite pervasively developed throughout the complex, they tend to be more prominent and abundant in the western part of the intrusion. Here they often occur as rather extensive pil-
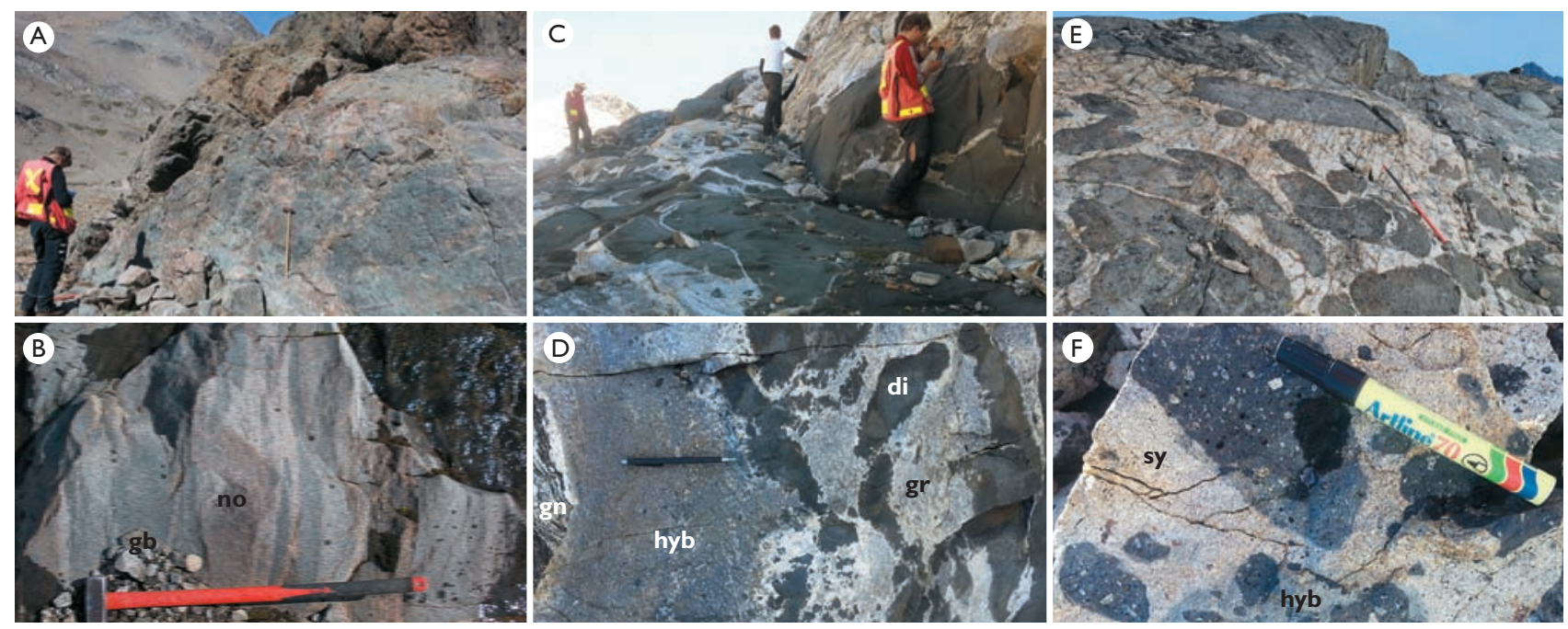

Fig. 2. Examples of composite magmatic systems intruded at different crustal levels. A, B: The Tasiilaq Intrusion representing deep to middle crustal levels. A: Leuconorite intruding melagabbro in a semi-molten state. B: Mingling structures with lensoidal wavy contacts between leuconorite (no) and melagabbro (gb). C, D: The Ikaasartivaq intrusive complex intruded at intermediate to upper crustal levels. C: A c. $5 \mathrm{~m}$ wide composite mafic-felsic dyke intruded into gneiss basement. D: Contact of dyke with gneiss (gn) wall rock, marginal zone of hybridised magma (hyb), and interior part of dark, distorded diorite pillows (di) in pale granite (gr) matrix; note crenulated, chilled margins in diorite. E, F: The Kialineq Intrusive Centre that represents a shallow intrusion $(<5 \mathrm{~km})$. E: A $4-5 \mathrm{~m}$ wide composite sheet of syenite with up to metre-sized mafic pillows in diorite. F: Composite dyke in the syenite body (sy) at Laube Gletscher showing evidence of mingling and hybridisation on a small scale. 
low complexes that texturally resemble the mafic-felsic mixed rocks in the Kialineq Intrusive Centre (see below). The complex also hosts a range of composite dykes and sills, some of which are texturally similar to the classical net-veined complexes in Iceland. Mingling and mixing features within these smaller bodies include cauliflower textures, irregular margins between mafic globules and felsic host melt (Fig. 2C, D), and decimetre- to several metre-scale mafic pillows within felsic material. The margins of intrusive features and edges of individual mafic globules commonly show signs of hybridisation as indicated by intermediate coloured rocks (Fig. 2D).

Kialineq Intrusive Centre - The Kialineq Intrusive Centre is located c. $200 \mathrm{~km}$ north of Tasiilaq (Fig. 1) in an extremely rugged terrain. It is dominated by gabbro-diorite-syenitegranite plutons and is cut by numerous coast-parallel mafic dykes. Many of the plutons are closely associated with extensive mafic-felsic mixed magma complexes (Brooks 2011 and references therein). Only a few radiometric ages are available, but they appear to show a bimodal distribution with mafic magmatism at 56-49 Ma, represented by the mafic Imilik intrusion, followed by a hiatus and subsequent activity at 37$35 \mathrm{Ma}$ of plutons with more evolved compositions (Larsen et al. 2014). Although the chronology is poorly constrained, it agrees with the field observations and suggests a general sequence of emplacement of gabbro, mafic dykes, mafic-felsic complexes, syenite and granite.

Mafic-felsic complexes, often referred to as net-veined complexes, are widespread and ubiquitous in the Kialineq district, and have also been reported elsewhere from the NAIP (Nielsen 2002). The vertical extent of the mafic-felsic complexes is rarely well exposed in the Kialineq Intrusive Centre, but field evidence suggests that these complexes can be at least $400 \mathrm{~m}$ thick. Although the field relationships are complex and vary substantially with locality, they show that the maficfelsic complexes are dominated by dioritic pillows surrounded by comagmatic syenites (Fig. 2E). The pillows range in size from c. 0.1 to $2 \mathrm{~m}$ in diameter and consist of fine- to mediumgrained diorite, typically coarsening from rim to centre with some pillows having chilled rims against the syenites. This implies a significant thermal gradient existed between the two liquids. More typical sensu stricto net-veined textures of angular mafic blocks separated by rather homogeneous syenite matrix also occur. Such breccia-type textures testify that the basic material in some cases was partly solidified when the syenite was emplaced. In contrast, the pillow complexes suggest synmagmatic interaction and mingling that demonstrate the co-existence of mafic and felsic liquids. Hybridisation was observed at the Laube Gletscher (Fig. 2F), but is generally rare in the area. Interestingly, vesicles and centimetre-sized miarolitic cavities are common features in Kialineq intrusive rocks, showing that exsolution of gaseous phases occurred. These exsolution features, along with the occurrences of ring dykes and bell-jar plutons, indicate a shallow emplacement depth in a subvolcanic (cauldron) environment.

\section{Discussion, summary and outlook}

We have described three examples of mafic-felsic complexes in south-eastern Greenland that show distinct mingling features irrespective of diverse geological settings, level of emplacement in the crust and compositional range. Here we briefly discuss the main differences between the three areas in order to constrain the key responsible processes that generated the observed features.

The Tasiilaq intrusion represents a deep crustal end-member of the study area. Compared to the other two examples, the mingled lithologies of the Tasiilaq intrusion (leuconorite and melagabbro) contrast less strongly in composition, and so large differences in solidus temperatures are unlikely. Further support for this hypothesis is offered by the lack of chilled margins at lithological contacts, although this could in part also reflect the slow cooling of the intrusion. The textural relationships between the two main lithologies are consistent with leuconorite being intruded into melagabbro at a point where the latter was partly solidified. The mingling-like features are often smeared out defining a general WNW-ESE orientation, suggesting a syn-magmatic influence from the regional stress field of the orogen. Overall, the Tasiilaq intrusion seems to record a markedly different and more tectonised image of mingling relations between magmas of minor compositional contrast than shown by the other two examples.

The mingling features found in the Ikaasartivaq intrusive complex and the Kialineq Intrusive Centre show many overall similarities, but also some notable differences. Both areas represent fairly high crustal levels as opposed to the Tasiilaq intrusion and contain an apparent bimodality of magma compositions (often referred to as the 'Daly Gap'), including diorite and syenite/granite as end-members. The common observation in both systems are chilled mafic pillows or blobs in contact with felsic melts, indicating that a considerable temperature contrast existed between the respective mingling liquids. This excludes a model in which the mingling components are formed by silicate liquid immiscibility processes that otherwise are believed to be important in many magmatic systems.

Only limited evidence for hybridisation is seen in the Kialineq Intrusive Centre as compared to the common occurrence in the Ikaasartivaq intrusive complex (Fig. $2 \mathrm{C}$ vs. Fig. 2E). This could reflect differences in a range of parameters, 
especially in the crustal level. Since temperature gradients between magma and host rock are greater at shallow crustal levels, the time window for mixing and hybridisation in the Kialineq system is expected to be shorter. This may account for better preservation of end-member compositions in the Kialineq Intrusive Centre than the other two examples studied. In all three areas studied, the scales at which mafic and felsic components mingle to form blobs of different sizes probably reflect multiple factors, such as contrasts in viscosity, temperature and density of the mingling magmas, the relative abundance of mafic to felsic magmas. It is beyond the scope of this paper to discuss these parameters in detail, but we suggest that blob development indicates an environment where differences in magma temperatures are small. Unsurprisingly, these features are found in the largest intrusions. Cauliflower textures with grain size reduction indicate environments with stronger thermal gradients and these are typically found in the shallower environments or in smaller, sill or sheet-like bodies.

In summary, igneous rocks in south-eastern Greenland provide abundant evidence for bimodal magmatism, and magma mingling, mixing and hybridisation in different tectonic settings and crustal levels. Key differences between the three areas relate partly to various extents of mingling vs. hybridisation and partly to textural and structural characteristics of the interface between mafic and felsic components (e.g. blob vs. pillow size, extent of grain-size reduction, degree of surface crenulation). The governing factors are several, including (1) depth of emplacement which determines thermal conditions and cooling rates, (2) differences in magma-intensive parameters for the sets of dual end-members (temperature, density, viscosity, chemical composition, crystal contents), (3) the relative proportions of the mafic and silicic end-members, and (4) size and geometry of the intrusive bodies (small dykes or sheets vs. large magma chamber systems).

Future work aims to qualify the reasons for the differences in more detail, to assess how the region fits into a broader understanding of magmatism and petrogenesis in different tectonic settings and to investigate the coupled chemical and physical dynamics of juxtaposed magmas. One aspect will be to understand how the mingling features relate to the geological setting and intrusion shape, and investigate how these rocks compare to net-veined complexes in rift settings and andesites in arc and collisional settings. Another aspect regards the origin of the apparent bimodality and understanding the role of magma mixing as a process masking the compositional gap. Detailed petrological, geochemical and isotopic studies will be carried out to characterise endmember components in order to address the petrogenetic link between the mafic and felsic components. This will help to distinguish between models of fractional crystallisation versus partial melting of the Archaean crust and to explain the apparent bimodality.

\section{Acknowledgements}

The work is part of the SEGMENT project that aims to evaluate the economic potential of the larger Tasiilaq area and to gather geological information in general and is financed by the Ministry of Industry and Mineral Resources in Greenland and the Geological Survey of Denmark and Greenland. Special thanks to Christian Tegner, Chip Lesher and Thomas Ulrich for collaborative fieldwork in the Kialineq area.

\section{References}

Andersen, T., Austrheim, H. \& Bridgwater, D. 1989: P-T and fluid evolution of the Angmagssalik "Charnockite" Complex, SE Greenland. In: Bridgwater, D. (ed.): Fluid movements - element transport and the composition of the deep crust, 71-94. Dordrecht: Kluwer Academic Publishers.

Brooks, C.K. 2011: The East Greenland rifted volcanic margin. Geological Survey of Denmark and Greenland Bulletin 24, 96 pp.

Hansen, B. \& Kalsbeek, F. 1989: Precise age for the Ammassalik Intrusive Complex. Rapport Grønlands Geologiske Undersøgelser 146, 46-47.

Kalsbeek, F., Austrheim, H., Bridgwater, D., Hansen, B.T., Pedersen, S. \& Taylor, P.N. 1993: Geochronology of Archaean and Proterozoic events in the Ammassalik area, South-East Greenland, and comparisons with the Lewisian of Scotland and the Nagssugtoqidian of West Greenland. Precambrian Research 62, 239-270.

Kolb, J. 2014: Structure of the Palaeoproterozoic Nagssugtoqidian Orogen, South-East Greenland: model for the tectonic evolution. Precambrian Research 255, 809-822.

Larsen, L.M., Pedersen, A.K., Tegner, C. \& Duncan, R.A. 2014: Eocene to Miocene igneous activity in NE Greenland: northward younging of magmatism along the East Greenland margin. Journal of the Geological Society 171, 539-553.

Nielsen, T.F.D. 2002: Palaeogene intrusions and magmatic complexes in East Greenland, 66 to $75^{\circ}$ N. Danmarks og Grønlands Geologiske Undersøgelse Rapport 2002/113, 249 pp.

Sparks, S.R.J., Sigurdsson, H. \& Wilson, L. 1977: Magma mixing: a mechanism for triggering acid explosive eruptions. Nature 267, 315-318.

Sparks, R.S.J. \& Marshall, L.A. 1986: Thermal and mechanical constraints on mixing between mafic and silicic magmas. Journal of Volcanology and Geothermal Research, 29, 99-124.

Wright, A.W., Tarney, J., Palmer, K.F., Moorlock, B.S.P. \& Skinner, A.C. 1973: The geology of the Angmassalik area, East Greenland and possible relationships with the Lewisian of Scotland. In: Park R.G. \& Tarney, J. (eds): The Early Precambrian of Scotland and related rocks of Greenland, 157-177. Keele: University of Keele.

Authors' address
Geological Survey of Denmark and Greenland, Øster Voldgade 10, DK-1350 Copenhagen K, Denmark. E-mail: tfk@geus.dk 